\title{
Adsorptive Removal of a Reactive Azo Dye Using Polyaniline-Intercalated Bentonite
}

\author{
Jingxi Tie ${ }^{1,3 *}$, Xiaohong Fang ${ }^{1 * *}$, Xiaolei Wang ${ }^{1}$, Yao Zhang ${ }^{1}$, Tian Gu ${ }^{1}$, \\ Shujun Deng ${ }^{2}$, Guoting Li ${ }^{1}$, Dengyong Tang ${ }^{3}$ \\ ${ }^{1}$ School of Environmental and Municipal Engineering, North China University of Water Resources and Electrical Power, \\ Zhengzhou, 450011, PR China \\ ${ }^{2}$ School of Resources and the Environment, North China University of Water Resources and Electrical Power, \\ Zhengzhou, 450011, PR China \\ ${ }^{3}$ School of Environmental Science and Engineering, Nanjing University of Information Science and Technology, \\ Nanjing, 210044, PR China
}

Received: 20 May 2016

Accepted: 5 December 2016

\begin{abstract}
For this study we conducted a series of adsorption experiments to study the adsorption performance of reactive red 2 (RR-2), a typical anionic dye, on polyaniline-intercalated bentonite (Pani-Bent). The adsorbent was characterized by XRD, FTIR, SEM, TEM, and BET. We investigated the influences of several parameters, including $\mathrm{pH}$, reaction time, temperature, inorganic salts, and initial concentrations. The results indicate that the adsorption of RR-2 is better in an acidic solution. Both $\mathrm{NaCl}$ and $\mathrm{Na}_{2} \mathrm{SO}_{4}$ can improve RR-2 uptake. The adsorption process follows the pseudo second-order kinetic model. The non-linear regression method was adopted to analyze the obtained equilibrium data in terms of the Langmuir, Freundlich, Temkin, Dubinin-Radushkevich (D-R), and Flory-Huggins models. The Langmuir isotherm fits the equilibrium data best among the five models, and the adsorption capacity increases from 202.0 to $257.7 \mathrm{mg} / \mathrm{g}$ as the temperature increases from $5^{\circ} \mathrm{C}$ to $33^{\circ} \mathrm{C}$ Pani-Bent can be an efficient adsorbent for adsorption removal of RR-2 from its aqueous solutions.
\end{abstract}

Keywords: adsorption, polyaniline-intercalated bentonite, reactive red 2, kinetics, isotherm

\section{Introduction}

As synthetic anionic dyes, reactive dyes consist of azo-containing chromophores and various reactive groups, including vinyl sulfone, chlorotriazine, trichloropyrimidine, and difluorochloropy rimidine [1]. The

*e-mail: 15202843@qq.com,

**e-mail: fang_xh@qq.com active groups in the dye molecules can react with the cellulosic fiber to form a covalent bond during the dyeing process in the basic environment [2-3]. This type of dye has been used widely with the increasing usage of the cotton in textile industries, and more than $50 \%$ of cotton is dyed with reactive dyes due to its excellent washing fastness, bright colors, abundant color shades, and easy application since the first commercial reactive dye was introduced for cotton by ICI in the 1950s [2, 4-5]. Currently, they account for almost half of global annual production of commercial dyes [6]. However, the features of high water solubility, 
relatively low fixation efficiency, and the formation of the useless hydrolyzed dye in basic condition $(\mathrm{pH}>10.5)$ has led to a $20-50 \%$ loss of their total consumption in the dyeing process into effluents [7-8]. The discharge of large volumes of dye-bearing effluents causes increasing environmental concern since the presence of the residual dye even at a very low concentration can cause aesthetic problems. Furthermore, their azo bonds and aromatic rings make them toxic, mutagenic, and carcinogenic to living organisms. Therefore, removal of the residual dyes from dyeing effluents is deeply necessary before they are discharged into water bodies.

Conventional bio-systems are less effective for dyebearing wastewater treatment due to the fact that the complex and stable chemical structures of synthetic azo dyes make them resistant to bio-degradation. Therefore, physical and chemical methods, including coagulation [9], adsorption [10-11] membrane filtration [12-13], and advanced oxidation [14-15] are employed to treat dye wastewater. Among these techniques, adsorption is attracting increasing interest due to its properties of simple operation, high performance, and low running cost [1617]. Both natural and synthetic materials have been used as adsorbents to remove dyes from wastewater [18-19]. As natural clay, bentonite has been used widely as an adsorbent for much pollutant removal, including PPCPs, heavy metal, VOCs, etc. [20-22], due to its advantages such as large specific surface area, good cation exchange capacity, and excellent chemical and physical stability [23]. Unfortunately, raw bentonite is inefficient for reactive dye adsorption as a result of the repulsion between its negatively charged surface and the anionic dye molecules. Hence, improving its anionic dye adsorption capacity by modification is the key challenge to its application for treating wastewater containing reactive dyes.

In this study, the synthesized polyaniline-intercalated bentonite (Pani-Bent) was characterized and used as a potential adsorbent to remove a typical reactive azo dye, reactive red 2 (RR-2), from its synthetic solution. We investigated the effects of various parameters, such as $\mathrm{pH}$, reaction time, inorganic salts, etc. on RR-2 removal. The isotherm and kinetic were evaluated as well.

\section{Materials and Methods}

\section{Characterization of Samples}

The adsorbent used in this study was synthesized in the same way as that described in our previous study [24]. The morphological information of the sodium bentonite (Na-Bent) and polyaniline-intercalated bentonite (Pani-Bent) were characterized by using SEM (JSM6460LV, Japan Electronic Co., Ltd.) and TEM (JEM2100Plus, Japan Electronic Co., Ltd.). The BET surface areas of the two samples were analyzed by a surface area and porosity analyzer (Autosorb-I, Quantachrome, USA).

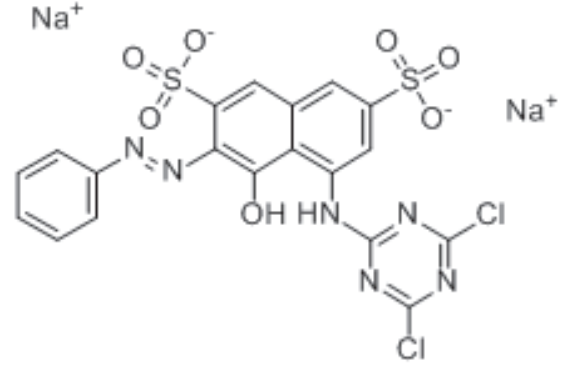

Fig. 1. Chemical structure of RR-2 (chemical formula: $\mathrm{C}_{19} \mathrm{H}_{10} \mathrm{Cl}_{2} \mathrm{~N}_{6} \mathrm{Na}_{2} \mathrm{O}_{7} \mathrm{~S}_{2}$, molecular weight: 615.33).

\section{Preparation of Artificial Wastewater}

The RR-2 solution used in this study was prepared by dissolving RR-2 purchased via the internet without further purification into distilled water. The $\mathrm{pH}$ was adjusted using $0.1 \mathrm{M} \mathrm{NaOH}$ and $0.1 \mathrm{M} \mathrm{HCl}$ solutions and measured using a pH meter (pHS-3C, Leici Ltd., China). All the reagents used were of analytical grade. The chemical structure of RR-2 is illustrated in Fig. 1.

\section{Adsorption Experiments}

The batch RR-2 adsorption experiments were conducted in $100 \mathrm{~mL}$ stoppered conical flasks. The flasks were filled with $0.03 \mathrm{~g}$ of Pani-Bent and $20 \mathrm{~mL}$ of RR-2 solutions and shaken at $130 \mathrm{rpm}$ over a period of time at fixed temperature. The $\mathrm{pH}$ values of the solutions were kept at a defined value $(7.0 \pm 0.1)$ apart from the test of the $\mathrm{pH}$ effect. After the adsorption experiments, the solutions were centrifuged at $8,000 \mathrm{rpm}$ for $10 \mathrm{~min}$, and the residual RR-2 concentrations in supernatants were determined using a Uv-vis spectrophotometer (UV-5100, Yuanxi Instruments, Shanghai, China) at its longest adsorption wavelength of $\lambda=538 \mathrm{~nm}$ [25]. RR-2 uptake by Pani-Bent is calculated using the following equation:

$$
q=\frac{\left(C_{0}-C_{e}\right) V}{m}
$$

...where $q$ is the RR-2 uptake by per unit Pani-Bent $(\mathrm{mg} / \mathrm{g}) ; C_{0}$ and $C_{e}(\mathrm{mg} / \mathrm{L})$ are the initial and final RR-2 concentrations, respectively; $V(\mathrm{~L})$ is the RR-2 solution volume; and $m$ is the amount of Pani-Bent (g). (Note that the mean values of three independent experiments are used in this article, and experimental errors are calculated and expressed with error bars.)

\section{Results and Discussion}

\section{Characterization of Samples}

As shown in our previous study, the XRD patterns indicate that the interlayer spacing increases from 

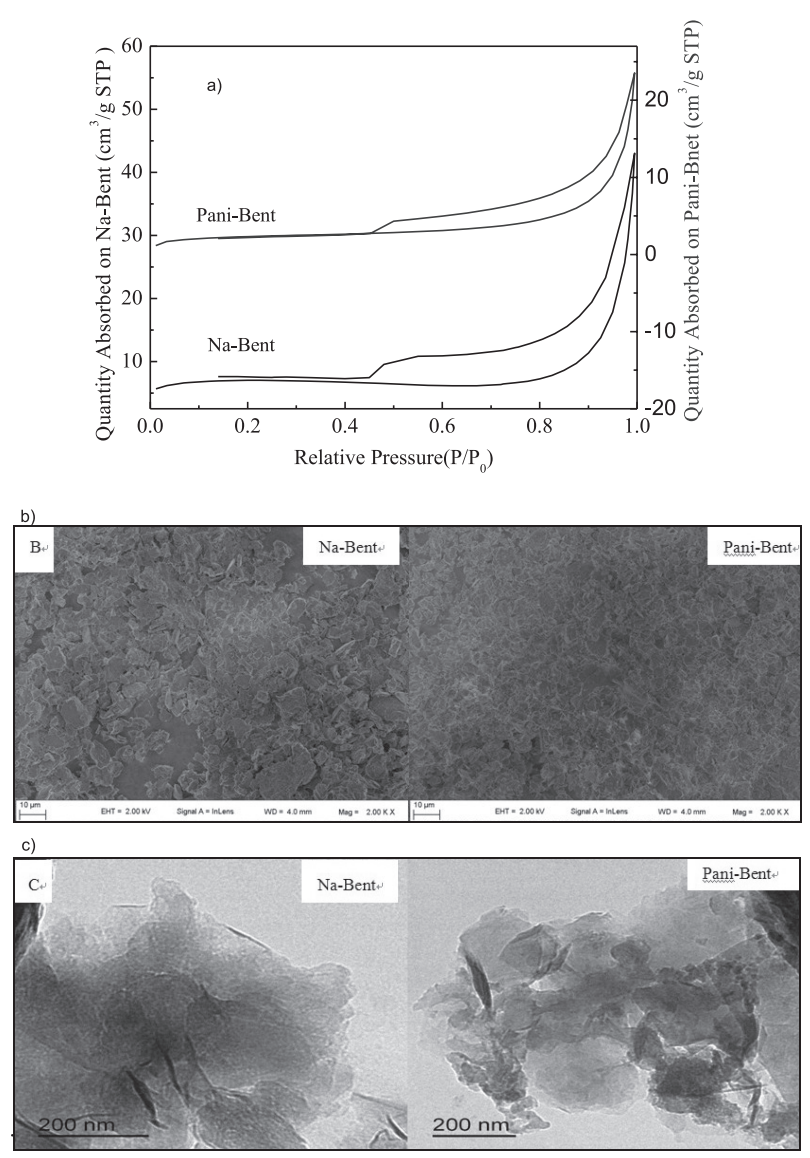

Fig. 2. Characterizations of Na-Bent and Pani-Bent by BET a), SEM b), and TEM c).

$14.77 \AA$ for purified bentonite to $15.61 \AA$ for PaniBent. Meanwhile, there are some characteristic peaks of polyaniline appearing in the FT-IR spectrum of Pani-Bent [24].

Fig. 2a) shows the $\mathrm{N}_{2}$ adsorption-desorption isotherm on the Na-Bent and Pani-Bent. The isotherms of the two samples fit the type IV isotherm with hysteresis loop, indicating the existence of both mesopore and macropore in the two samples. Table 1 summarizes the specific surface areas using the BET method. Compared with NaBent, the specific surface area and the total pore volume of Pani-Bent decreases dramatically from 22.74 to $8.24 \mathrm{~m}^{2} / \mathrm{g}$ and from 0.04 to $0.022 \mathrm{~cm}^{3} / \mathrm{g}$, respectively. These changes might result from the fact that the micropores in the interlayer of Na-Bent are blocked by the polymerization of aniline, whereas the decrease of micropores results in the increase of average pore size from 6.68 to $10.51 \mathrm{~nm}$.

Fig. 2b) shows the SEM image of Na-Bent and PaniBent. The image of Na-Bent shows its typical layered structure. Compared with Na-Bent, the particle size of Pani-Bent is smaller, resulting from a cleavage fracture caused by the polymerization of aniline.

Fig. 2c) shows the TEM image of Na-Bent and PaniBent. The TEM image of Na-Bent shows its dense layered structure, whereas the layered structure of Pani-Bent is relatively loose, and granular polyaniline can be found in its image.
Table 1. Brunner-Emmet-Teller (BET) measurements of NaBent and Pani-Bent.

\begin{tabular}{|c|c|c|c|}
\hline Samples & $\begin{array}{c}\text { Specific surface } \\
\text { area }\left(\mathrm{m}^{2} \cdot \mathrm{g}^{-1}\right)\end{array}$ & $\begin{array}{c}\text { Total pore } \\
\text { volume } \\
\left(\mathrm{cm}^{3} \cdot \mathrm{g}^{-1}\right)\end{array}$ & $\begin{array}{c}\text { Average } \\
\text { pore size } \\
(\mathrm{nm})\end{array}$ \\
\hline Na-Bent & 22.74 & 0.040 & 6.68 \\
\hline Pani-Bent & 8.24 & 0.022 & 10.51 \\
\hline
\end{tabular}

\section{Effect of $\mathrm{pH}$}

Solution $\mathrm{pH}$ plays a very important role in the adsorption process due to the fact that $\mathrm{pH}$ variation can change both the surface charges of adsorbent and the existing forms of adsorbate $[19,26]$. So we investigated RR-2 uptake as a function of $\mathrm{pH}$, and the result is shown in Fig. 3. It can be seen that RR-2 uptake decreases from $140.8 \mathrm{mg} / \mathrm{g}$ to $120.8 \mathrm{mg} / \mathrm{g}$ as the solution $\mathrm{pH}$ increases from 5 to 9 , indicating that RR-2 adsorption on Peni-Bent is a $\mathrm{pH}$ dependent process. The same variation of RR-2 uptake as a function of $\mathrm{pH}$ was observed when positively charged metapenaeus monoceros shells and $\mathrm{Fe}_{3} \mathrm{O}_{4} /$ chitosan nanoparticles were used as adsorbents [27-28]. Qureshi et al. reported that the PZC (point of zero electric charge) of bentonite is negative in all ranges of $\mathrm{pH}$. Hence, the raw bentonite is inefficient for anionic dye adsorption due to electrostatic repulsion. After modification with polyaniline, its PZC is around $\mathrm{pH} 5$, caused by the electrostatic interactions between PANI and bentonite surface charges, namely its PZC is positive in the range of $\mathrm{pH}<5$ and negative in the range of $\mathrm{pH}>5$ [29]. Hence, RR-2 uptake decreases as $\mathrm{pH}$ increases from 5 to 9 . Meanwhile, the competition between the RR-2 molecules and increasing $\mathrm{OH}^{-}$groups for the active sites are the other cause of the decreased uptake of RR-2 at higher $\mathrm{pH}$ [30].

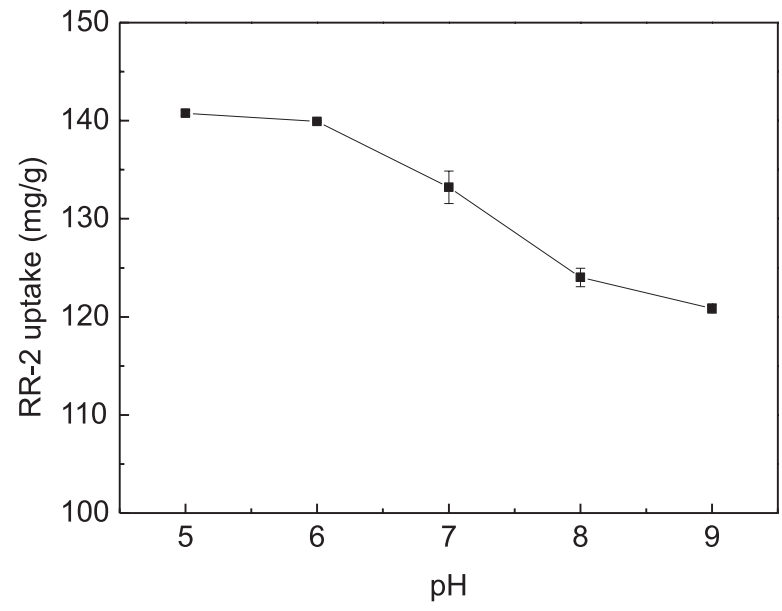

Fig. 3. Effect of $\mathrm{pH}$ on RR-2 adsorption on Pani-Bent $\left(\mathrm{T}=25^{\circ} \mathrm{C}\right.$, contact time $=24 \mathrm{~h}$ ). 


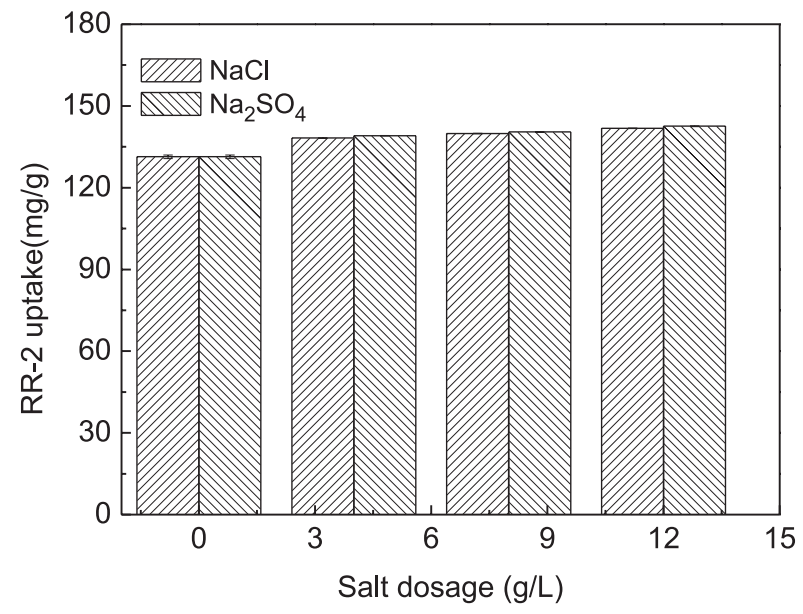

Fig. 4. Effect of inorganic salts on RR-2 adsorption on Pani-Bent $\left(\mathrm{T}=25^{\circ} \mathrm{C}\right.$, contact time $\left.=24 \mathrm{~h}\right)$.

\section{Effect of Inorganic Salts}

Dyeing wastewater always contains a large amount of inorganic salts since the inorganic salts are widely used as dyeing promoter in the dyeing process to improve dye-uptake by driving the dye molecules out of solution onto the fiber [24]. Hence we investigated the removal efficiency as a function of two typical inorganic salts, $\mathrm{NaCl}$ and $\mathrm{Na}_{2} \mathrm{SO}_{4}$, which are widely used for dyeing. As shown in Fig. 4, RR-2 uptake increases from $131.4 \mathrm{mg}$ $\mathrm{g}^{-1}$ to 141.8 and $142.6 \mathrm{mg} / \mathrm{g}$ as $\mathrm{NaCl}$ and $\mathrm{Na}_{2} \mathrm{SO}_{4}$ increase from 0 to $12 \mathrm{~g} / \mathrm{L}$, respectively. This could be explained by the fact that the inorganic salts increased the aggregation of the dye molecules, leading to the improvement of RR-2 uptake on the Pani-Bent surface [31]. Momenzadeh et al. reported that $\mathrm{NaCl}$ and $\mathrm{Na}_{2} \mathrm{SO}_{4}$ increased the adsorption of reactive red 120 on chitosan nanodispersion due to the same reason [32]. However, the two salts decrease the adsorption of reactive blue 4 on modified guar gum and silica-based nanocomposite since the H-bonding formed between the salt anions and nanocomposites weakened the reaction between the dye molecules and active sites on the surface of nanocomposites [33].

\section{Effect of Contact Time and Adsorption Dynamics}

Fig. 5 shows the RR-2 uptake as a function of contact time at two different initial concentrations. It can be seen that there is a fast adsorption of RR-2 within the first 15 min for both of the two RR-2 initial concentrations since the Pani-Bent surfaces offered more free active sites in this stage, indicating that chemical adsorption might be the main mechanism for RR-2 uptake in this stage. The adsorption takes place slowly in the following stage, and reaches the practical equilibriums at 1,440 $\mathrm{min}$ because there were fewer active sites available for adsorption. Additionally, the molecules absorbed on active sites repelled the free dye molecules in solution to approach the

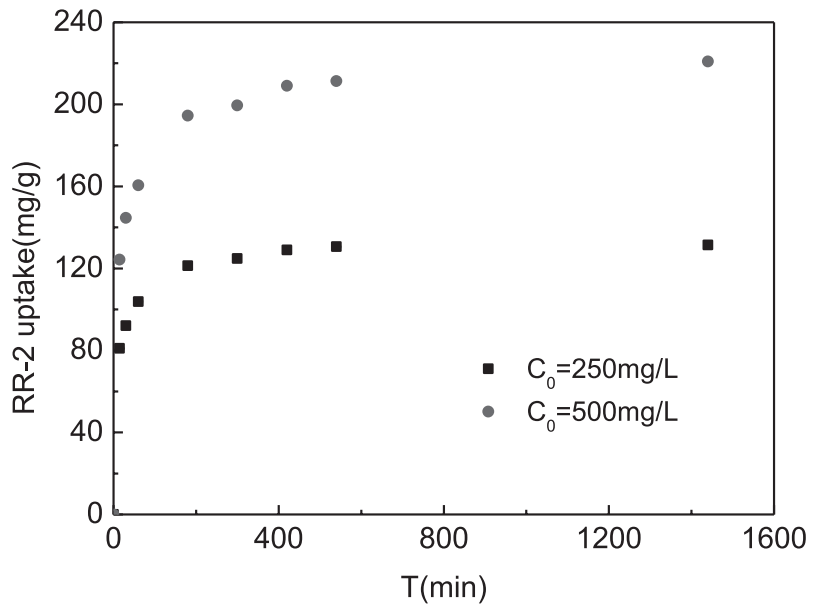

Fig. 5. Effect of contact time on RR-2 adsorption on Pani-Bent $\left(\mathrm{T}=25^{\circ} \mathrm{C}\right)$.

surface of Pani-Bent, leading to slower adsorption [19]. In the following experiments, $24 \mathrm{~h}$ is chosen as the reaction time to ensure equilibrium.

A good adsorbent for water treatment must have a fast adsorption rate apart from a large adsorption capacity. Hence four adsorption kinetic models, including the pseudo first-order kinetic model, pseudo second-order model, the Elovich model, and intra-particle diffusion model are adopted to test the adsorption processes of RR-2 by Pani-Bent [34-37].

\section{Pseudo First-Order Kinetics}

The linearized form of the pseudo first-order equation is given as:

$$
\log \left(q_{e}-q_{t}\right)=\log q_{e}-\frac{k_{1}}{2.303} t
$$

... where $q_{t}$ and $q_{e}(\mathrm{mg} / \mathrm{g})$ are the RR-2 uptake at time $t$ and at equilibrium. $k_{1}\left(\mathrm{~min}^{-1}\right)$ is the equilibrium rate constant of the pseudo first-order equation. The plots of $\log$ $\left(q_{e}-q_{t}\right)$ vs $t$ are shown in Fig. 6a), and $k_{1}$ and predicted $q_{e}$ can be determined from the slope and intercept of the plot, respectively.

\section{Pseudo Second-Order Kinetics}

The linearized form of the pseudo second-order equation is given as:

$$
\frac{t}{q_{t}}=\frac{t}{q_{e}}+\frac{1}{k_{2} q_{e}^{2}}
$$

...where $k_{2}[\mathrm{~g} /(\mathrm{mg} \mathrm{min})]$ is the equilibrium rate constant of the pseudo first-order equation. The plot of $\mathrm{t} / q_{t} \mathrm{vs} \mathrm{t}$ is shown in Fig. 6b), and $k_{2}$ and $q_{e}$ can be determined from the slope and intercept of the plot, respectively. 

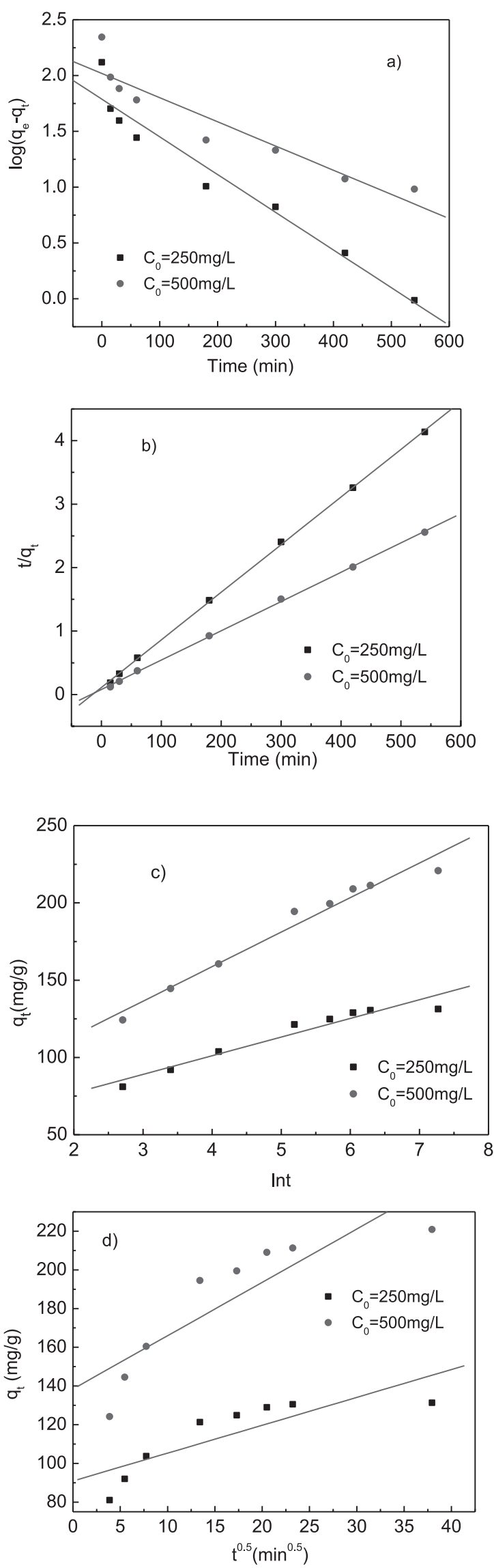

Fig. 6. The linearized plots of pseudo first-order kinetics a), pseudo second-order kinetics b), the Elovich model c), and intraparticle diffusion model d) for adsorption of RR-2 on Pani-Bent, $\left(\mathrm{T}=25^{\circ} \mathrm{C}\right)$

\section{Elovich Model}

The Elovich equation has been widely used to describe chemical adsorption with heterogeneous adsorbing surfaces [38]. The linearized form of the first-order equation is given as:

$$
q_{t}=\frac{1}{\beta} \ln (\alpha \beta)+\frac{1}{\beta} \ln t
$$

...where $\alpha[(\mathrm{mg} /(\mathrm{g} \mathrm{min})]$ is the initial adsorption rate and $\beta(\mathrm{g} / \mathrm{mg})$ is associated with the fraction of surface coverage and activation energy for chemisorption. The plot of $q_{t}$ vs. lnt is shown in Fig. 6c), and $\alpha$ and $\beta$ can be determined from the intercept and slope of the plot, respectively.

\section{Intra-Particle Diffusion Model}

The intra-particle diffusion model assumes that film diffusion is negligible and the only rate-controlling step is intra-particle diffusion in the adsorption process [39]. Hence, the adsorbed amount at time t should be directly proportional to $t^{0.5}$ rather than $t$. The model is given as:

$$
q_{t}=k_{i d} t^{0.5}+C
$$

...where $k_{i d}$ is the intra-particle diffusion rate constant $\left(\mathrm{mg} / \mathrm{g} \mathrm{min}{ }^{0.5}\right)$, which can be calculated from the slope of the linear plot of qt versus $t^{0.5}$ and can be determined from the slope of the plot shown in Fig. 6 d).

Table 2. Parameters of the three kinetic equations for RG-19 adsorption on Pani-Bent.

\begin{tabular}{|c|c|c|c|}
\hline $\begin{array}{c}\text { Kinetics } \\
\text { equations }\end{array}$ & Parameters & $250 \mathrm{mg} \mathrm{L}^{-1}$ & $500 \mathrm{mg} \mathrm{L}^{-1}$ \\
\hline \multirow{4}{*}{$\begin{array}{c}\text { Pseudo } \\
\text { first-order }\end{array}$} & $q_{e, \text { exp }}$ & 131.4 & 220.8 \\
\cline { 2 - 4 } & $\mathrm{q}_{e, \text { cal }}$ & 61.43 & 104.4 \\
\cline { 2 - 4 } & $k_{1}$ & 0.008 & 0.005 \\
\hline \multirow{3}{*}{$\begin{array}{c}\text { Pseudo } \\
\text { second-order }\end{array}$} & $R^{2}$ & 0.951 & 0.880 \\
\cline { 2 - 4 } & $\mathrm{q}_{e, \text { cal }}$ & 133.3 & 217.4 \\
\hline \multirow{3}{*}{\begin{tabular}{c} 
Elovich \\
\cline { 2 - 4 }
\end{tabular}} & $R^{2}$ & 0.0005 & 0.0002 \\
\cline { 2 - 4 } & $R^{2}$ & 0.999 & 0.999 \\
\hline \multirow{3}{*}{$\begin{array}{c}\text { Intra-particle } \\
\text { diffusion }\end{array}$} & $k_{i d}$ & 958.3 & 498.5 \\
\cline { 2 - 4 } & $C$ & 0.083 & 0.045 \\
\cline { 2 - 4 } & $R^{2}$ & 0.696 & 0.969 \\
\hline
\end{tabular}


The kinetic parameters calculated from the four linearized plots are shown in Table 2. The correlation coefficients of the pseudo second-order kinetics are higher than those of the other three models. The simulation results of $\mathrm{q}_{e, c a l}$ obtained from the equations are in good accordance with those of experiment values of $q_{e, \text { exp }}$ at the same time. The results suggest that the adsorption of RR-2 follows the pseudo second-order kinetics, indicating that the rate-determining step of the adsorption process might be chemical adsorption or chemisorption, and the valency forces between the adsorbent and adsorbate might be involved in the adsorption [40-41].

\section{Adsorption Isotherms Study}

In this study, the experimental equilibrium data of RR-2 onto Pani-bent are fitted with Langmuir, Freundlich, Temkin, Dubinin-Radushkevich (D-R), and FloryHuggins models.

\section{Langmuir Isotherm}

The Langmuir model was developed to describe monolayer adsorption on homogeneous surface with all active sites having identical adsorption energy [42]. Its linearized form is given as:

$$
\frac{C_{e}}{q_{e}}=\frac{1}{q_{m} b}+\frac{C_{e}}{q_{m}}
$$

... where $q_{m}(\mathrm{mg} / \mathrm{g})$ is the maximum monolayer adsorption capacity and $b(\mathrm{~L} / \mathrm{mg})$ is the Langmuir constant related to binding energy. The plots of $\mathrm{C}_{e}$ versus $\mathrm{C}_{e} / q_{e}$ are shown in Fig. 7a), and the values of $q_{m}$ and $b$ are calculated from the slope and intercept of the plots, respectively.

\section{Freundlich Isotherm}

The Freundlich model was developed to describe multilayer adsorption on a heterogeneous surface [43]. The linearized form of the Freundlich model is given as:

$$
\log q_{e}=\log k_{f}+\frac{1}{n} \log C_{e}
$$

...where $K_{f}(\mathrm{mg} / \mathrm{g})$ and $n$ are the Freundlich constants related to adsorption capacity and adsorption intensity, respectively. The plots of $\ln C_{e}$ versus $\ln q_{e}$ were shown in Fig. $7 b$ ), and the values of $1 / n$ and $k_{f}$ are calculated from the slope and intercept of the plots, respectively.

\section{Temkin Isotherm}

This model assumes a homogeneous distribution of binding energies and a linear decrease of adsorption heat of all the molecules in the layer with coverage because of the interactions between adsorbate and adsorbent [44]. Its linearized form was expressed as:

$$
\begin{gathered}
q_{e}=\frac{R T}{b} \ln A+\frac{R T}{b} \ln c_{e} \\
B=\frac{R T}{b}
\end{gathered}
$$

...where $R[(8.314 \mathrm{~J} /(\mathrm{mol} \mathrm{K})]$ is ideal gas constant, $T$ $(\mathrm{K})$ is the absolute reaction temperature, $B(\mathrm{~J} / \mathrm{mol})$ is the Temkin constant corresponding to adsorption heat, and $A(1 / \mathrm{g})$ is the binding constant related to the maximum binding energy at equilibrium. The plots of $\ln C$ versus $q_{e}$ are shown in Fig. 7c, and the values of $B$ and $A$ can be calculated from the slope and intercept of the plots, respectively.

\section{Dubinin-Radushkevich (D-R) Isotherm}

The D-R isotherm is usually adopted to describe adsorption with a Gaussian energy distribution onto a heterogeneous surface [44]. The model is given as:

$$
\begin{gathered}
\ln q_{e}=\ln q_{m}-k \varepsilon^{2} \\
\varepsilon=R T \ln \left(1+\frac{1}{C_{e}}\right) \\
E=\frac{1}{\sqrt{2 k}}
\end{gathered}
$$

...where $k$ is the $\mathrm{D}-\mathrm{R}$ isotherm constant $\left(\mathrm{mol}^{2} / \mathrm{kJ}^{2}\right)$. The plots of $\ln q_{e}$ versus $\varepsilon^{2}$ are shown in Fig. 7d), and the values of $k$ and $q_{m}$ are calculated from the slope and intercept of the plots, respectively.

\section{Flory-Huggins Isotherm}

The Flory-Huggins isotherm was developed to describe the surface coverage characteristic degree of adsorbate onto adsorbent, and the model is given as [45-46]:

$$
\begin{aligned}
\log \left(q_{e}-q_{t}\right) & =\log q_{e}-\frac{k_{1}}{2.303} t \\
\theta & =1-\frac{C_{e}}{C_{0}}
\end{aligned}
$$

... where $K_{F H}$ is equilibrium constant, $n_{F H}$ is the number of adsorbate ions occupying active sites, and $\theta$ is the surface coverage degree. The plots of $\log \left(\theta / \mathrm{C}_{0}\right)$ versus $\log (1-\theta)$ are shown in Fig. 7e), and the values of $K_{F H}$ and $n_{F H}$ can be calculated from the slope and intercept of the plots, respectively.

All the correlation coefficients, $\mathrm{R}^{2}$ values, and the constants calculated from the five models are listed in Table 3. The $R^{2}$ values of the Langmuir equation at all three temperatures are highest, indicating that the 

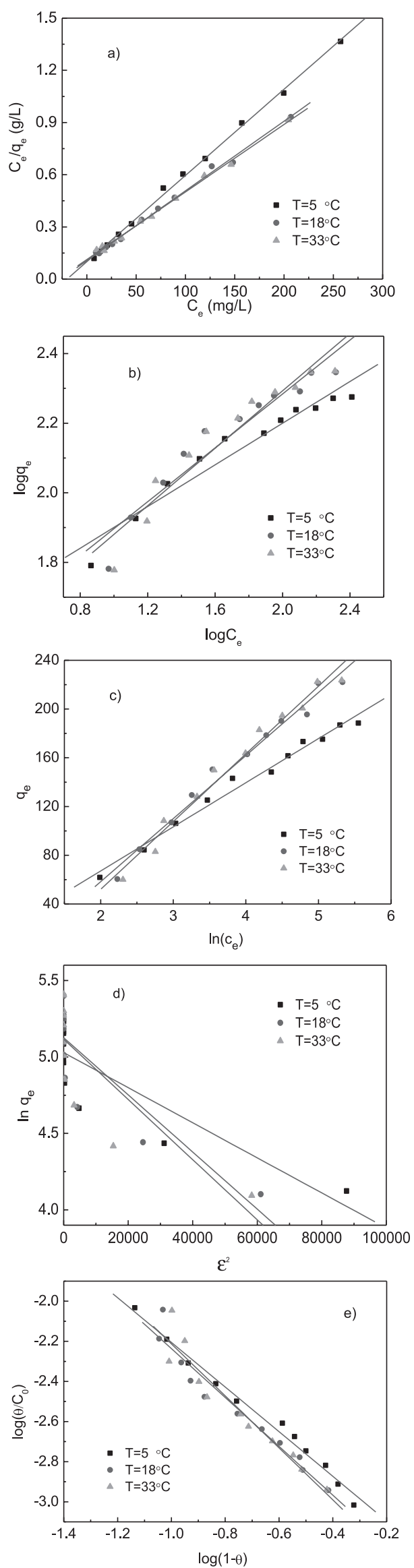

Fig. 7. Linearized plots of Langmuir isotherm a), Freundlich isotherm b), Temkin isotherm c), D-R isotherm d), and FloryHuggins isotherm e) for adsorption of RR-2 on Pani-Bent.
Table 3. Adsorption isotherm constants for adsorption of RR-2 on Pani-Bent.

\begin{tabular}{|c|c|c|c|}
\hline \multirow{2}{*}{ Isotherm model } & \multicolumn{3}{|c|}{ Reaction temperature $\left({ }^{\circ} \mathrm{C}\right)$} \\
\hline & 5 & 18 & 33 \\
\hline \multicolumn{4}{|c|}{ Langmuir isotherm } \\
\hline $\mathrm{q}_{\mathrm{m}}$ & 202.0 & 249.6 & 257.7 \\
\hline$b$ & 0.049 & 0.037 & 0.034 \\
\hline $\mathrm{R}^{2}$ & 0.9981 & 0.9957 & 0.9964 \\
\hline \multicolumn{4}{|c|}{ Freundlich isotherm } \\
\hline$n$ & 3.341 & 2.583 & 2.425 \\
\hline$k_{f}$ & 39.95 & 32.34 & 29.39 \\
\hline $\mathrm{R}^{2}$ & 0.9404 & 0.9228 & 0.9105 \\
\hline \multicolumn{4}{|c|}{ Temkin isotherm } \\
\hline$A$ & 0.863 & 0.417 & 0.345 \\
\hline B & 36.212 & 51.766 & 55.593 \\
\hline $\mathrm{R}^{2}$ & 0.9846 & 0.9817 & 0.9769 \\
\hline \multicolumn{4}{|c|}{$\mathrm{D}-\mathrm{R}$ isotherm } \\
\hline$K\left(10^{-6}\right)$ & 1.146 & 1.868 & 1.968 \\
\hline$q_{m}$ & 152.6 & 168.3 & 166.5 \\
\hline $\mathrm{E}$ & 295.4 & 231.3 & 225.4 \\
\hline $\mathrm{R}^{2}$ & 0.7453 & 0.7261 & 0.6588 \\
\hline \multicolumn{4}{|c|}{ Flory-Huggins isotherm } \\
\hline$n_{F H}$ & -1.113 & -1.218 & -1.297 \\
\hline$K_{F H}$ & 0.0362 & 0.0316 & 0.0299 \\
\hline $\mathrm{R}^{2}$ & 0.9877 & 0.9483 & 0.9225 \\
\hline
\end{tabular}

Langmuir equation is the best model to describe the adsorption of RR-2 on Pani-Bent. The Langmuir constant $q_{m}$ indicates the adsorption capacity of the Pani-Bent. As shown in Table 3, $q_{m}$ value is found to increase with rising temperature, indicating that higher temperature is favorable for RR-2 adsorption.

Table 4 compared the adsorption capacities of Pani-Bent with several adsorbents described in previous documents for the removal of RR-2. It can be seen that the maximum adsorption capacity of RR-2 on Pani-Bent ranks fourth among the 12 types of adsorbents, indicating that Pani-Bent is an efficient adsorbent for RR-2 removal from aqueous solutions. The use of Pani-Bent for RR-2 removal is of particular attraction because China has the largest reserves of bentonite in the world.

A dimensionless constant, $R_{L}$ (namely the separation factor), is used to describe the essential characteristics of the adsorption process. The constant is given as:

$$
R_{L}=\frac{1}{1+b c_{0}}
$$


Table 4. Monolayer adsorption capacities in the literature for adsorption of RR2 on different adsorbents.

\begin{tabular}{|c|c|c|c|}
\hline Adsorbents & $q_{m}(\mathrm{mg} / \mathrm{g})$ & $\begin{array}{c}\text { Operational } \\
\text { parameters } \\
\mathrm{T}\left({ }^{\circ} \mathrm{C}\right) / \mathrm{pH}\end{array}$ & Refer. \\
\hline Pani-Bent & $\begin{array}{l}202.0 \\
249.6 \\
257.7\end{array}$ & $\begin{array}{c}5 /- \\
18 /- \\
33 /-\end{array}$ & $\begin{array}{l}\text { This } \\
\text { study }\end{array}$ \\
\hline Mg-Al-LDH & 59.49 & $-/-$ & {$[48]$} \\
\hline $\begin{array}{c}\text { Surfactant } \\
\text { modified macro } \\
\text { fungus }\end{array}$ & $\begin{array}{l}0.134 \\
0.136 \\
0.142\end{array}$ & $\begin{array}{l}25 /- \\
35 /- \\
45 /-\end{array}$ & [49] \\
\hline $\begin{array}{l}\text { Positively } \\
\text { charged } \\
\text { metapenaeus } \\
\text { monoceros } \\
\text { shells }\end{array}$ & 303.03 & $30 / 2$ & {$[27]$} \\
\hline $\begin{array}{l}\text { Physical- } \\
\text { chemical- } \\
\text { treated sludge }\end{array}$ & $\begin{array}{c}213.9 \pm 4.9 \\
75.4 \pm 2.3 \\
217.7 \pm 2.3\end{array}$ & $\begin{array}{l}25 / 2 \\
25 / 4 \\
45 / 2\end{array}$ & \multirow{2}{*}[50]{} \\
\hline $\begin{array}{l}\text { Biologically } \\
\text { treated sludge }\end{array}$ & $\begin{array}{c}159.3 \pm 10.2 \\
83.3 .4 \pm 1.8 \\
152.5 .4 \pm 7.8\end{array}$ & $\begin{array}{l}25 / 2 \\
25 / 4 \\
45 / 2\end{array}$ & \\
\hline $\begin{array}{c}\mathrm{Fe}_{3} \mathrm{O}_{4} / \text { chitosan } \\
\text { nanoparticle }\end{array}$ & $\begin{array}{l}461.3 \\
475.9 \\
481.5\end{array}$ & $\begin{array}{l}25 / 2 \\
35 / 2 \\
45 / 2\end{array}$ & {$[28]$} \\
\hline $\begin{array}{c}{[\mathrm{Cu}(\text { bipy })} \\
\left.\left(\mathrm{SO}_{4}\right)\right]_{\mathrm{n}}\end{array}$ & 915 & $27 /-$ & {$[51]$} \\
\hline $\begin{array}{l}\text { metal } \\
\text { hydroxide } \\
\text { sludge }\end{array}$ & $\begin{array}{l}66.67 \\
61.73 \\
63.29 \\
58.14\end{array}$ & $\begin{array}{l}15 / 8-9 \\
30 / 8-9 \\
45 / 8-9 \\
60 / 8-9\end{array}$ & [17] \\
\hline $\mathrm{NH}_{3}^{+}-\mathrm{MCM}-41$ & 0.21 & $24.5 / 5.6$ & {$[52]$} \\
\hline $\begin{array}{c}\text { Organic } \\
\text { aerogels (AGs) } \\
\text { and carbon } \\
\text { aerogels (CAs) }\end{array}$ & $\begin{array}{cc}86(\mathrm{AG}) & 565(\mathrm{CA}) \\
97(\mathrm{AG}) & 578(\mathrm{CA}) \\
112(\mathrm{AG}) & 609(\mathrm{CA})\end{array}$ & $\begin{array}{l}25 /- \\
35 /- \\
45 /-\end{array}$ & {$[26]$} \\
\hline
\end{tabular}

Note: "-" in the table means no corresponding parameters.

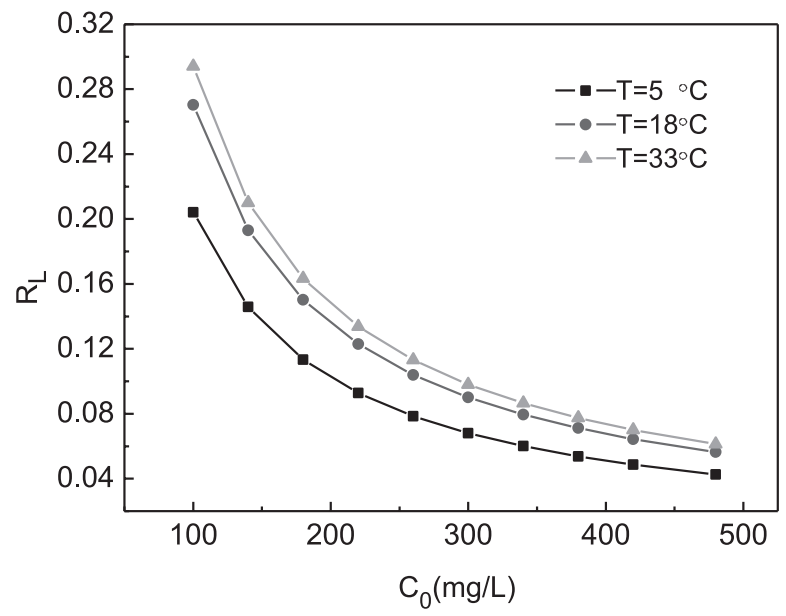

Fig. 8. Effect of initial RR-2 concentration on separation factor $\mathrm{R}_{\mathrm{L}}$ at different temperatures. ...where $c_{0}(\mathrm{mg} / \mathrm{L})$ is the initial RR-2 concentration and $b$ $(\mathrm{L} / \mathrm{mg})$ is the Langmuir constant.

Fig. 8 shows the effect of initial RR-2 concentrations on $R_{L}$ at three different temperatures. All the values of $R_{\mathrm{L}}$ are between 0 and 1, indicating that RR-2 adsorption is favorable in experimental conditions [47]. Higher RR-2 concentration is more favorable for adsorption since the $R_{\mathrm{L}}$ values tend to decrease as the initial concentrations increase from 100 to $480 \mathrm{mg} / \mathrm{L}$.

\section{Conclusion}

In this study we used Pani-Bent as an adsorbent to remove RR-2 from aqueous solutions. The results show that Pani-Bent is a good adsorbent for the removal of RR-2 from aqueous solutions over a wide range of concentrations. RR-2 uptake decreases with rising $\mathrm{pH}$ value of solution. Two inorganic salts, $\mathrm{NaCl}$ and $\mathrm{Na}_{2} \mathrm{SO}_{4}$, increase RR-2 adsorption by prompting aggregation of the dye molecules. The adsorption of RR-2 increases with increased contact times and the adsorption belongs to the second-order kinetic model. Five isotherm models, including Langmuir, Freundlich, Temkin, D-R and FloryHuggins isotherms, are used to fit the equilibrium data, and the Langmuir isotherm is demonstrated to be the best model for adsorption. The separation factor, $R_{L}$ for all the initial concentrations at three reaction temperatures, are less than 1, indicating the favorable nature of RR-2 adsorption on Pani-Bent.

\section{Acknowledgements}

This work is financially supported by opening fund of state key library of pollution control \& resource reuse of Nanjing University (No. PCRRF12016).

\section{References}

1. MAHMOUD M.S. Decolorization of certain reactive dye from aqueous solution using Baker's Yeast (Saccharomyces cerevisiae) strain. HBRC J. 12, 88, 2016.

2. TAYLOR J.A., KHALID PASHA., PHILLIPS D.A.S. The dyeing of cotton with hetero bi-functional reactive dyes containing both a monochlorotriazinyl and a chloroacetylamino reactive group, Dyes Pigments. 51 (2-3), 145, 2001.

3. RIZK H.F., IBRAHIM S.A., EL-BORAI M.A. Synthesis, fastness properties, color assessment and antimicrobial activity of some azo reactive dyes having pyrazole moiety. Dyes Pigments. 112, 86, 2015.

4. KHATRI A., PEERZADA M.H., MOHSIN M., WHITE M. A review on developments in dyeing cotton fabrics with reactive dyes for reducing effluent pollution. J. Clean Prod. 87, 50, 2015.

5. ROSA J.M., FILETI A.M.F., TAMBOURGI E.B., SANTANA J.C.C. Dyeing of cotton with reactive dyestuffs: the continuous reuse of textile wastewater effluent treated by Ultraviolet/Hydrogen peroxide homogeneous photocatalysis. J. Clean. Prod. 90, 60, 2015. 
6. GHOREISHIAN S.M., BADII K., NOROUZI M., RASHIDI A., MONTAZER M., SADEGHI M., VAFAEE $M$. Decolorization and mineralization of an azo reactive dye using loaded nano-photocatalysts on spacer fabric: Kinetic study and operational factors. J. Taiwan Ins. Chem. Eng. 45, 2436, 2014.

7. WANGPRADIT R., CHITPRASERT P. Chitosancoated Lentinus polychrous Lév. Integrated biosorption and biodegradation systems for decolorization of anionic reactive dyes. Int. Biodeter. Biodeg. 93, 168, 2014.

8. SHAMSHAD A., MUGHAL M., SHOUKAT U., BALOCH M., KIM S. H. Cationic starch (Q-TAC) pre-treatment of cotton fabric: Influence on dyeing with reactive dye. Carbohyd. Polym. 117, 27, 2015.

9. TIE J.X., JIANG M.B., LI H.C. ZHANG S. ZHANG X.W. A Comparison between moringa oleifera seed presscake extract and polyaluminum chloride in the removal of direct black 19 from synthetic wastewater. Ind. Crop. Prod. 74, 530, 2015.

10. KHAN M.M.R., MUKHLISH M.Z.B., MAZUMDER M.S.I., FERDOUS K., PRASAD D.M.R., HASSAN Z. Uptake of indosol dark-blue GL dye from aqueous solution by water hyacinth roots powder: adsorption and desorption study. Int. J. Environ. Sci. Technol. 11 (4), 1027, 2014.

11. SANKAR M.K., KUMAR K.M., RANGANATHAN B.V. Adsorption of anionic azo dye from aqueous solution using strychnos potatorum linn seeds: isotherm and kinetic studies. Int. J. Environ. Sci. Technol. 12, 2957, 2015.

12. HASSANI A.H, MIRZAYEE R., NASSERI S., BORGHEI M., GHOLAMI M., TORABIFAR B. Nanofiltration process on dye removal from simulated textile waste water. Int. J. Environ. Sci. Technol. 5 (3), 401, 2008.

13. MASMOUDI G., TRABELSI R., ELLOUZE E., AMAR R.B. New treatment at source approach using combination of microfiltration and nanofiltration for dyeing effluents reuse. Int. J. Environ. Sci. Technol. 11 (4), 1007, 2014.

14. DIVYA N., BANSAL A., JANA A.K. Photocatalytic degradation of azo dye orange II in aqueous solutions using copper-impregnated titania. Int. J. Environ. Sci. Technol, 10 (6), 1265, 2013.

15. CHAMJANGALI M.A., BAGHERIAN G., BAHRAMIAN B., RAD B.F. Synthesis and application of multiple rods gold-zinc oxide nanostructures in the photocatalytic degradation of methyl orange. Int. J. Environ. Sci. Techenol. 12 (1), 151, 2015.

16. CHATTERJEE S., MIN W., LEE S.H. Adsorption of congo red by chitosan hydrogel beads impregnatedwith carbon nanotubes. Bioresource Technol, 101 (6), 1800, 2010.

17. NETPRADIT S., THIRAVETYAN P., TOWPRAYOON S. Application of 'waste' metal hydroxide sludge for adsorption of azo reactive dyes. Water Res. 37 (4), 763, 2003.

18. OLAJIRE A.A., GIWA A. A., BELLO I.A. Competitive adsorption of dye species from aqueous solution onto melon husk in single and ternary dye systems. Int. J. Environ. Sci. Technol. 12 (3), 939, 2015.

19. ZHANG C., YANG S.G., CHEN H.Z., HE H., SUN C. Adsorption behavior and mechanism of reactive brilliant red $\mathrm{X}-3 \mathrm{~B}$ in aqueous solution over three kinds of hydrotalcitelike LDHs. Appl. Surf. Sci. 301, 329, 2014.

20. BARBOOTI M.M., SU H., PUNAMIYA P., SARKAR D. Oxytetracycline sorption onto Iraqi montmorillonite. Int. J. Environ. Sci. Technol. 11 (1), 69, 2014.

21. LIU Z.R., ZHOU S.Q. Adsorption of copper and nickel on Na-bentonite. Process Safe. Environ. Protect. 88 (1), 62, 2010.
22. HOU X.J., LI H.Q., HE P., LI S.P., LIU Q.F., Molecular-level investigation of the adsorption mechanisms of toluene and aniline on natural and organically modified montmorillonite. J. Phys. Chem. 119 (45), 11199, 2015.

23. ZAGHOUANE-BOUDIAF H., BOUTAHAL M., SAHNOUN S., TIAR C., GOMRI F. Adsorption characteristics, isotherm, kinetics, and diffusion of modifiednatural bentonite for removing the 2,4,5-trichlorophenol, App. Clay Sci. 90, 81,2014.

24. TIE J.X., CHEN D.G., ZHAO M.Q., WANG X.L., ZHOU S.G., PENG L.G. Adsorption of Reactive Green 19 from water using Polyaniline/Bentonite. J. Water Reuse Desal. (2016)

25. LIN C.C., LIN Y.S.,HO J.M. Adsorption of Reactive Red 2 from aqueous solutions using $\mathrm{Fe}_{3} \mathrm{O}_{4}$ nanoparticles prepared by co-precipitation in a rotating packed bed. J. Alloy. Compd. 666, 153, 2016.

26. WU X. B., WU D. C., FU R. W., Studies on the adsorption of reactive brilliant red X-3B dye on organic and carbon aerogels. J. Hazard. Mater. 147 (3), 1028, 2007.

27. THIYAGARAJAN E., SARAVANAN P., DEVI S.S., SARANYA P., GANDHI N.N., RENGANATHAN. Biosorption of reactive red 2 using positively charged metapenaeus monoceros shells. J Saudi Chem Soc, DOI:10.1016/j.jscs.2013.05.004

28. CAO C.H., XIAO L., CHEN C.H., SHI X.W., CAO Q.H., GAO L. In situ preparation of magnetic $\mathrm{Fe}_{3} \mathrm{O}_{4}$ /chitosan nanoparticles via a novel reduction-precipitation method and their application in adsorption of reactive azo dye. Powder Technol, 260, 90, 2014.

29. QURESHI U.A., GUBBUK I.H., ERSOZ M., SOLANGI A.R., TAQVI S.I.H., MEMON S.Q. Preparation of polyaniline montmorillonite clay composites for the removal of diethyl hexyl phthalate from aqueous solutions. Sep. Sci. Technol, 51, 214, 2016.

30. ANSARI R., KEIVANI M.B., DELAVAR A.FA. Application of polyaniline nanolayer composite for removalof tartrazine dye from aqueous solutions. J. Polym. Res. 18, 1931, 2011.

31. AL-DEGS Y.S., EL-BARGHOUTHI MUSA I., EL-SHEIKH A.H., WALKER G. M. Effect of solution pH, ionic strength, and temperature on adsorption behavior of reactive dyes on activated carbon. Dyes Pigments. 77 (1), $16,2008$.

32. MOMENZADEH H., TEHRANI-BAGH A.R., KHOSRAVI A., GHARANJIG K., HOLMBERG K. Reactive dye removal from wastewater using a chitosan nanodispersion. Desalination. 271 (1-3), 225, 2011.

33. PAL S., PATRA A.S., GHORAI S., SARKAR A.K., MAHATO V., SARKAR S, SINGH R.P. Efficient and rapid adsorption characteristics of templating modified guar gum and silica nanocomposite toward removal of toxic reactive blue and congo red dyes, Bioresource Technol. 191, 291, 2015.

34. PATHAKA P.D., MANDAVGANE S.A. Preparation and characterization of raw and carbon from banana peel by microwave activation: Application in citric acid adsorption. J. Environ. Chem. Eng. 3, 2435, 2015.

35. FAKHRI A., ADAMI S. Adsorption and thermodynamic study of Cephalosporins antibiotics from aqueous solution onto $\mathrm{MgO}$ nanoparticles. J.Taiwan Inst. Chem. Eng. 45, 1001, 2014.

36. FAKHRI A., BEHROUZ S. Comparison studies of adsorption properties of $\mathrm{MgO}$ nanoparticles and $\mathrm{ZnO}$ $\mathrm{MgO}$ nanocomposites for linezolid antibiotic removal from aqueous solution using response surface methodology. Process Saf. Environ. Protect. 94, 37, 2015. 
37. FAKHRI A. Assessment of Ethidium bromide and Ethidium monoazide bromide removal from aqueous matrices by adsorption on cupric oxide nanoparticles. Ecotox. Environ. Saf. 104, 386, 2014.

38. WU F.C., TSENG R.L., JUANG R.S. Characteristics of Elovich equation used for the analysis of adsorption kinetics in dye-chitosan systems. Chem. Eng. J. 150, 366, 2009.

39. OKOYE A.I., EJIKEME P.M., ONUKWULI O.D. Lead removal from wastewater using fluted pumpkin seed shell activated carbon: Adsorption modeling and kinetics. Int. J. Environ. Sci. Tech., 7 (4), 793, 2010

40. FAKHRI A. Investigation of mercury (II) adsorption from aqueous solution onto copper oxide nanoparticles: Optimization using response surface methodology. Process Saf. Environ. Protect. 93, 1, 2015.

41. ÖRNEK A., ÖZACAR M., ŞENGIL İ.A. Adsorption of lea d onto formaldehyde or sulphuric acid treated acorn waste: Equilibrium and kinetic studies. Biochem. Eng. J. 37 (2), 192, 2007.

42. ÜNLÜ NURI, ERSOZ M. Removal of heavy metal ions by using dithiocarbamated-sporopollenin. Sep. Puri. Technol. 52 (3), 461, 2007.

43. VU D., LI Z.H.Y., ZHANG H.N, WANG W., WANG ZHAOJIE.J., XU X.R., DONG B., WANG C. Adsorption of $\mathrm{Cu}$ (II) from aqueous solution by anatase mesoporous $\mathrm{TiO}_{2}$ nanofibers prepared via electrospinning. J. Colloid Interf. Sci. 367, 429, 2012.

44. DADA A.O., OLALEKAN A.P., OLATUNYA A.M., DADA, O. Langmuir, Freundlich, Temkin and DubininRadushkevich Isotherms Studies of Equilibrium Sorption of $\mathrm{Zn}^{2+}$ onto phosphoric acid modified rice husk. IOSR J. App. Chem. 3 (1), 38, 2012.
45. SAADI R., SAADI Z., FAZAELIR., FARD N.E Monolayer and multilayer adsorption isotherm models for sorption from aqueous media, Korean J. Chem. Eng., 32 (5), 787, 2015

46. JNR M.H., SPIFF A.I. Equilibrium sorption study of $\mathrm{Al}^{3+}$, $\mathrm{Co}^{2+}$ and $\mathrm{Ag}^{+}$in aqueous solutions by fluted pumpkin (Telfairia Occidentalis HOOK f) waste biomass. Acta Chim. Slov. 52, 174, 2005.

47. HAMEED B.H., TAN I.A.W., AHMAD A.L. Adsorption isotherm, kinetic modeling and mechanism of 2,4,6-trichlorophenol on coconut husk-based activated carbon. Chem. Eng. J. 144 (2), 235, 2008.

48. SHAN R., YAN L., YANG Y., YANG K., YU S., YU H., ZHU B., DU B. Highly efficient removal of three red dyes by adsorption onto $\mathrm{Mg}$-Al-layered double hydroxide. J. Ind. Eng. Chem. 21, 561, 2015.

49. AKAR T., DIVRIKLIOGLU M. Biosorption applications of modified fungal biomass for decolorization of Reactive Red 2 contaminated solutions: Batch and dynamic flow mode studies. Bioresource Technol. 101 (19), 7271, 2010.

50. GABRIELA G., SELENE M.A. GUELLI U.S., DEBORA O., ANTONIO A.U.S. The application of textile sludge adsorbents for the removal of Reactive Red 2 dye. J. Environ. Manage. 168, 149, 2016.

51. XIAO L., XIONG Y., TIAN S., HE C., SU Q., WEN Z. One-dimensional coordination supramolecular polymer $\left[\mathrm{Cu} \text { (bipy) }\left(\mathrm{SO}_{4}\right)\right]_{\mathrm{n}}$ as an adsorbent for adsorption and kinetic separation of anionic dyes. Chem. Eng. J. 265, 157, 2015.

52. QIN Q.D., MA J., LIU K. Adsorption of anionic dyes on ammonium-functionalized MCM-41. J. Hazard. Mater. 162 (1), 133, 2009. 